Reviu Akuntansi dan Bisnis Indonesia, Vol. 4 No. 1, Hlm: 28-36, Juli 2020

Website: http://journal.umy.ac.id/index.php/rab

\title{
Faktor-Faktor yang Memengaruhi Kinerja Auditor Internal Pemerintah Provinsi Daerah Istimewa Yogyakarta (Studi Empiris Pada Kantor Inspektorat Provinsi Daerah Istimewa Yogyakarta)
}

\author{
Wahyu Hapsari ${ }^{1 *}$ \& Erny Suryandari Fathmaningrum ${ }^{1}$ \\ 'Program Studi Akuntansi Univeritas Muhammadiyah Yogyakarta.
}

I N F O A R T I K E L

\section{Kata Kunci:}

Independensi, Komitmen Organisasi, Pemahaman

Good Governance,

Ketidakjelasan Peran,

Kinerja Auditor.

Jenis Artikel:

Penelitian Empiris

Korespondensi:

w.hapsari23@gmail.com

\section{A B S T R A K}

\section{Latar Belakang:}

Pemerintah yang bersih dapat diciptakan dengan menerapkan aspek yang dapat mendukung kinerja pemerintah dan didukung dengan pihak-pihak yang menolak untuk berbuat kecurangan demi kepentingan pribadi, auditor pemerintah adalah salah satu aspek penting untuk menciptakan sistem pemerintah yang bersih karena banyaknya ketidakberesan, ketidakbenaran, serta ketidakteraturan dalam pengelolaan dan tanggung jawab aparat pemerintah terhadap keuangan daerah serta aset negara yang dikelola secara tidak layak dan dilaporakan secara tidak wajar pada laporan keuangan yang dapat merugikan negara.

Tujuan:

Penelitian ini bertujuan untuk menguji Pengaruh Independensi, Komitmen Organisasi, Pemahaman Good Governance, Ketidakjelasan Peran, terhadap Kinerja Auditor Internal Pemerintah di Provinsi Daerah Istimewa Yogyakarta.

Metode Penelitian:

Penelitian ini menggunakan data primer yang bersifat kuantitatif yang berasal dari jawaban responden dalam bentuk kuesioner. Penelitian ini menggunakan sampel auditor yang bekerja pada Kantor Inspektorat Provinsi Daerah Istimewa Yogyakarta. Teknik pengambilan sampel dalam penelitian ini menggunakan metode purposive sampling. Alat analisis yang digunakan dalam penelitian ini menggunakan SPSS versi 22, dengan metode analisis data yaitu analisis regresi linear berganda.

\section{Hasil Penelitian:}

Penelitian ini menggunakan data primer yang bersifat kuantitatif yang berasal dari jawaban responden dalam bentuk kuesioner. Penelitian ini menggunakan sampel auditor yang bekerja pada Kantor Inspektorat Provinsi Daerah Istimewa Yogyakarta. Teknik pengambilan sampel dalam penelitian ini menggunakan metode purposive sampling. Alat analisis yang digunakan dalam penelitian ini menggunakan SPSS versi 22, dengan metode analisis data yaitu analisis regresi linear berganda.

Keterbatasan Penelitian:

Penelitian ini terbatas untuk Inspektorat wilayah Daerah Istimewa Yogyakarta, maka masih perlu dilakukan penelitian lebih lanjut untuk mengetahui Kinerja Auditor Internal Pemerintah Provinsi Daerah lainnya. Keaslian/Novetly Penelitian:

Penelitian kinerja auditor masih terus berkembang, khususnya untuk wilayah provinsi. Maka, penelitian ini memberikan diskusi baru untuk bidang audit untuk wilayah provinsi.

(C) 2020 RAB. Published by Universitas Muhammadiyah Yogyakarta DOI: $10.18196 /$ rab.040150 


\section{PENDAHULUAN}

Pemerintah yang bersih dapat diciptakan dengan menerapkan aspek yang dapat mendukung kinerja pemerintah dan didukung dengan pihak-pihak yang menolak untuk berbuat kecurangan demi kepentingan pribadi, auditor pemerintah adalah salah satu aspek penting untuk menciptakan sistem pemerintah yang bersih karena banyaknya ketidakberesan, ketidakbenaran, serta ketidakteraturan dalam pengelolaan dan tanggung jawab aparat pemerintah terhadap keuangan daerah serta aset negara yang dikelola secara tidak layak dan dilaporakan secara tidak wajar pada laporan keuangan yang dapat merugikan negara. Penyimpangan yang terjadi di negara Indonesia semakin lama semakin meningkat hal ini dibuktikan dari website Komisi Pemberantas Korupsi (KPK) survey terbaru yang dilakukan tahun 2017 oleh Transparency International, Indonesia menempati posisi 96 dari 180 negara pada indeks Persepsi Korupsi 2017 serta memperoleh indeks dalam daftar 37.

Dalam menjalankan tugasnya auditor tentu harus memperhatikan kode etik dan standar audit yang harus ditepati agar menghasilkan kinerja yang baik dan benar. Standar audit harus diterapkan pada auditor untuk menjaga mutu hasil audit yang telah dihasilkan oleh auditor, serta kode etik yang ditujukan agar auditor dapat menjaga perilakunya dalam menjalankan tugasnya (Trisnaningsih, 2007). Dengan adanya standar audit dan kode etik sebagai modal dasar auditor dalam menjalankan pengauditan sehingga peran auditor akan lebih maksimal dan hal ini sangat penting dalam mendukung BPKP dalam melakukan pemeriksaan.

Auditor dituntut untuk memiliki kinerja yang baik dalam BPKP. Kinerja auditor adalah suatu tindakan dan pelaksanaan tugas pemeriksaan yang telah diselesaikan oleh auditor dalam kurun waktu yang telah di tetapkan. Suatu kinerja (prestasi kerja) yang dapat diukur dengan pengukuran tertentu (standar), kualitas yang berkaitan dengan mutu kerja yang dihasilkan, dan kuantitas merupakan jumlah hasil kerja yang telah dicapai dalam kurun waktu yang telah ditentukan, serta ketepatan waktu merupakan kesesuaian pada waktu yang telah direncanakan.

Kinerja auditor adalah suatu pelaksanaan tindakan atas tugas pemeriksaan yang telah diselesaikan oleh auditor pada waktu tertentu. Trisnaningsih (2007), mengemukaan kinerja auditor merupakan evaluasi terhadap pekerjaan yang telah dilakukan atasan, rekan, dan dapat disimpulkan bahwa kinerja merupakan sebuah hasil karya yang dicapai oleh auditor dalam pelaksanaan tugas yang di berikan atas dasar kecakapan, pengalaman, serta kesungguhan waktu dengan pertimbangan kuantitas, kualitas, dan ketepatan.

\section{METODE PENELITIAN}

Penelitian ini dilaksanakan di Kantor Inspektorat Provinsi Daerah Istimewa Yogyakarta. Populasi dalam penelitian ini adalah Auditor senior maupun junior yang berada di Kantor Inspektorat Provinsi Daerah Istimewa Yogyakarta. Jenis data yang digunakan dalam penelitian ini meliputi data kuantitatif, berupa nilai atau skor atas jawaban yang diberikan oleh responden terhadap pertanyaan yang ada dalam kuesioner. Berdasarkan sumbernya, data yang digunakan adalah data primer yaitu data yang didapatkan secara langsung dari hasil penelitian pada Kantor Inspektorat Daerah Istimewa Yogyakarta. Teknik pengambilan sampel dilakukan dengan metode purposive sampling. Purposive sampling merupakan teknik pengambilan sampel yang digunakan dengan menggunakan kriteria khusus terhadap sampel (Ikhsan, 2008). Kriteria-kriteria atas sampel dalam penelitian ini adalah telah memiliki pengalaman pemeriksaan tim (2) tahun dengan mempertimbangkan bahwa auditor telah bekerja dan memiliki masa kerja minimal 1 tahun yang dapat dianggap memiliki waktu dan pengalaman. 
HASIL DAN PEMBAHASAN

Tabel 1

Tingkat Pengembalian Kuesioner

\begin{tabular}{lcc}
\hline \multicolumn{1}{c}{ Keterangan } & Jumlah & Persentase \\
\hline Kuesioner yang disebar & 40 & $100 \%$ \\
Kuesioner yang kembali & 40 & $100 \%$ \\
Kuesioner yang tidak dapat diolah & 3 & $7,5 \%$ \\
Kuesioner yang dapat diolah & 37 & $92,5 \%$ \\
\hline
\end{tabular}

Sumber: Data Primer yang diolah, 2019

Responden pada penelitian ini adalah Auditor senior dan junior di pemerintah Penyebaran data dalam penelitian ini dengan menggunakan metode langsung. Auditor yang sesuai dengan kriteria terkumpul 37 orang. Jumlah kuesioner yang dibagikan 40 kuesioner, kuesioner yang sesuai dengan kriteria sejumlah 37 dikarenakan 3 responden tidak sesuai dengan kriteria.

Tabel 2

Statistik Deskriptif

\begin{tabular}{lccccc}
\hline & N & Minimum & Maximum & Mean & Std. deviation \\
\hline Indepedensi & 37 & 27 & 45 & 37.16 & 8.1456 \\
Komitmen Organisasi & 37 & 36 & 60 & 47.16 & 11.4567 \\
Good Governance & 37 & 27 & 40 & 32.11 & 7.8133 \\
Ketidakjelasan Peran & 37 & 19 & 30 & 23.91 & 3.3879 \\
Kinerja Auditor Pemerintah & 37 & 22 & 30 & 26.81 & 4.0964 \\
\hline
\end{tabular}

Tabel 2 menunjukkan tabel statistik deskriptif masing-masing variabel, dimana variabel indepedensi memiliki nilai minimum sebesar 27 dengan nilai maksimum sebesar 45, adapun nilai rata-ratanya sebesar 37,16 dengan std. deviation sebesar 8,1456. Selanjutnya variabel komitmen organisasi dengan nilai minimum sebesar 36 dengan nilai maksimum sebesar 60, adapun nilai rataratanya sebesar 47,16 dengan std.dev sebesar 11,4567.

Variabel good governance memiliki nilai minimum sebesar 27 dengan nilai maksimum sebesar 40, adapun n,lai rata-ratanya adalah 32,11 dengan std.dev sebesar 7,8133. variabel ketidakjelasan peran memiliki nilai minimum sebesar 19 dengan nilai maksimum sebesar 30, adapun nilai rataratanya sebesar 23,91 dengan std.dev sebesar 3,3879. variabel terakhir yaitu variabel kinerja auditor pemerintah yang merupakan variabel dependen memiliki nilai minimum sebesar 22 denan nilai maksimum sebesar 30, adapun nilai rata-ratanya sebesar 26,81 dengan std.dev sebesar 4,0964

Tabel 3

Karakteristik Responden Berdasarkan Jenis Kelamin

\begin{tabular}{lccc}
\hline & Keterangan & Jumlah & Persentase \\
\hline Pria & & 21 & $56,8 \%$ \\
Wanita & 16 & $43,2 \%$ \\
Total & 37 & $100 \%$ \\
\hline
\end{tabular}

Sumber: Data Primer yang diolah, 2019

Data pada tabel 3 menunjukkan bahwa sebagian besar auditor internal pemerintah yang bekerja di Kantor Inspektorat Provinsi Daerah Istimewa Yogyakarta berjenis kelamin pria yaitu sebanyak 21 orang dengan jumlah persentase $56,8 \%$ dan yang berjenis kelamin wanita yaitu sebanyak 16 orang dengan jumlah presantase $43,2 \%$. 
Tabel 4

Karakteristik Responden Berdasarkan Pendidikan Terakhir

\begin{tabular}{lcc}
\hline \multicolumn{1}{c}{ Keterangan } & Jumlah & Persentase \\
\hline SMA & 1 & $2,7 \%$ \\
Strata Satu (S1) & 19 & $51,4 \%$ \\
Strata Dua (S2) & 17 & $45,9 \%$ \\
Total & 37 & $100 \%$ \\
\hline
\end{tabular}

Sumber: Data Primer yang diolah, 2019

Data pada tabel 4 menunjukkan bahwa sebagian besar auditor internal pemerintah yang bekerja di Kantor Inspektorat Provinsi Daerah Istimewa Yogyakarta mempunyai latar belakang pendidikan Strata satu (S1) yaitu sebanyak 19 orang dengan jumlah presentase 51,4\%.

Tabel 5

Karakteristik Responden Berdasarkan Lama Bekerja Sebagai Auditor

\begin{tabular}{clccc}
\hline No & & Keterangan & Jumlah & Persentase \\
\hline 1 & 1-2 tahun & 4 & $10,8 \%$ \\
2 & 2-5 tahun & 13 & $35,1 \%$ \\
3 & $5-10$ tahun & 13 & $35,1 \%$ \\
4 & $10-15$ tahun & 4 & $10,8 \%$ \\
5 & $>15$ tahun & 3 & $8,1 \%$ \\
Total & & 37 & $100 \%$ \\
\hline
\end{tabular}

Sumber: Data Primer yang diolah, 2019

Data pada tabel 5 menunjukkan bahwa sebagian besar auditor internal pemerintah yang bekerja di Kantor Inspektorat Provinsi Daerah Istimewa Yogyakarta mempunyai lama bekerja yaitu rentan tahun 2-5 tahun dan 5-10 tahun yaitu masing-masing sebanyak 13 orang dengan presentase $35,1 \%$.

Tabel 6

Hasil Uji Validitasz

\begin{tabular}{lc}
\hline \multicolumn{1}{c}{ Variabel } & Nilai KMO \\
\hline Independensi & 0,589 \\
Komitmen Organisasi & 0,713 \\
Good Governance & 0,595 \\
Ketidakjelasan Peran & 0,767 \\
Kinerja Auditor Pemerintah & 0,760 \\
\hline
\end{tabular}

Sumber: Data Primer yang diolah, 2019

Tabel 6 menunjukan bahwa nilai KMO Independensi 0,589>0,50, maka Variabel Independensi dapat dikatakan valid. Nilai KMO Komitmen Organisasi 0,713 > dari 0,50 maka variabel Komitmen Organisasi dapat dkatakan valid. Nilai KMO Good Governance 0,595 > 0,50 maka dapat dinyatakan variabel Good Governance valid. Nilai KMO Ketidakjelasan Peran 0,767 $>0,50$ maka variabel Ketidakjelasan Peran valid. Nilai KMO untuk variabel Kinerja Auditor Pemerintah adalah 0,760>0,50 maka dapat dinyatakan variabel Kinerja Auditor valid. 
Tabel 7

Hasil Uji Reliabilitas

\begin{tabular}{ll}
\hline Variabel & Nilai Cronbach Alpha \\
\hline Independensi & 0,819 \\
Komitmen Organisasi & 0,864 \\
Good Governance & 0,823 \\
Ketidakjelasan Peran & 0,844 \\
Kinerja Auditor Pemerintah & 0,899 \\
\hline
\end{tabular}

Sumber: Data Primer yang diolah, 2019

Berdasarkan tabel 7 diatas menunjukan nilai Croncbach Alpha Independensi sebesar 0,819, Komitmen Organisai sebesar 0,864, Good Governance sebesar 0,823, Ketidakjelasan Peran sebesar 0,823, dan yang terakhir Kinerja Auditor sebesar 0,899, dilihat dari nilai tersebut maka reliabilitas tinggi.

Tabel 8

Hasil Uji Normalitas

\begin{tabular}{ll}
\hline Asymp. Sig (2-Tailed) & Keterangan \\
\hline 0,661 & Residual Terdistribusi Normal \\
\hline Sumber: Data Primer yang diolah, 2019 &
\end{tabular}

Berdasarkan tabel 8 didapatkan hasil bahwa nilai sig sebesar 0,661 > $\alpha(0,05)$. Sehingga dapat ditarik kesimpulan bahwa residual berdistribusi normal.

Tabel 9

Hasil Uji Multikolinearitas

\begin{tabular}{|c|c|c|}
\hline Variabel & VIF & Keterangan \\
\hline Independensi & 1,771 & Bebas Multikolinearitas \\
\hline Komitmen Organisasi & 2,004 & Bebas Multikolinearitas \\
\hline Good Governance & 1,447 & Bebas Multikolinearitas \\
\hline Ketidakjelasan Peran & 1,398 & Bebas Multikolinearitas \\
\hline
\end{tabular}

Sumber: Data Primer yang diolah, 2019

Berdasarkan tabel 9 didapatkan hasil bahwa VIF masing-masing variabel kurang dari 10 . Variabel independsi 1,771, lalu variabel Komitmen Organisasi 2,004, Variabel Good Governance 1,447, dan variabel terakhir ketidakjelasan peran 1,398 sehingga tidak terjadi multikolinearitas.

Tabel 10

Hasil Uji Heteroskedastisitas

\begin{tabular}{lcc}
\hline \multicolumn{1}{c}{ Variabel } & Sig \\
\hline Independensi & 0,192 & \\
Komitmen Organisasi & 0,220 & \\
Good Governance & 0,436 & \\
Ketidakjelasan Peran & 0,495 & \\
\hline
\end{tabular}

Sumber: Data Primer yang diolah, 2019

Berdasarkan tabel 10 variabel Independensi 0,192, variabel Komitmen Organisasi 0,220, Variabel Good Governance 0,436, dan variabel ketidakjelasan Peran 0,495, menunjukkan terbebas dari heteroskedastisitas dikarenakan nilai sig lebih besar dari 0,05. 
Tabel 11

Hasil Uji $t$

\begin{tabular}{lcc}
\hline \multicolumn{1}{c}{ Variabel } & Nilai Sig & Koefisien regresi \\
\hline Independensi & 0,044 & 0,140 \\
Komitmen Organisasi & 0,033 & 0,018 \\
Good Governance & 0,012 & 0,333 \\
Ketidakjelasan Peran & 0,976 & $-0,006$ \\
\hline
\end{tabular}

Sumber: Data Primer yang diolah, 2019

\section{a. Pengujian Hipotesis Pertama $\left(\mathbf{H}_{1}\right)$}

Hasil Pengujian hipotesis variabel Independensi memiliki nilai koefisien regresi 0,140 dan memiliki nilai sig 0,044 nilai tersebut lebih kecil dari alpha 0,05 sehingga dapat dikatakan bahwa variabel Independensi berpengaruh positif terhadap kinerja auditor pemerintah. Maka dapat disimpulkan hipotesis pertama diterima.

\section{b. Pengujian Hipotesis Kedua $\left(\mathbf{H}_{2}\right)$}

Hasil Pengujian hipotesis variabel Komitmen Organisasi memiliki nilai koefisien regresi 0,018 dan memiliki nilai sig 0,033 nilai tersebut lebih kecil dari alpha 0,05 sehingga dapat dikatakan bahwa variabel Komitmen Organisai berpengaruh positif terhadap kinerja auditor pemerintah. Maka dapat disimpulkan hipotesis kedua diterima.

\section{c. Pengujiam Hipotesis Ketiga $\left(\mathrm{H}_{3}\right)$}

Hasil Pengujian hipotesis variabel Good Governance memiliki nilai koefisien regresi 0,339 dan memiliki nilai sig 0,012 nilai tersebut lebih kecil dari alpha 0,05 sehingga dapat dikatakan bahwa variabel Good Governance berpengaruh positif terhadap kinerja auditor pemerintah. Maka dapat disimpulkan hipotesis ketiga diterima.

\section{d. Pengujian Hipotesis Keempat $\left(\mathrm{H}_{4}\right)$}

Hasil Pengujian hipotesis variabel Ketidakjelasan Peran memiliki nilai koefisien regresi -0,016 dan memiliki nilai sig 0,976 nilai tersebut lebih besar dari alpha 0,05 sehingga dapat dikatakan bahwa variabel Ketidakjelasan Peran tidak berpengaruh negatif terhadap kinerja auditor pemerintah. Maka dapat disimpulkan hipotesis keempat ditolak.

Tabel 12

Hasil uji $\boldsymbol{F}$ (Simultan)

\begin{tabular}{llll}
\hline & Model & Sig. & \\
\hline 1 & Regression & & $.044(\mathrm{a})$ \\
& Residual & & \\
& Total & & \\
\hline
\end{tabular}

Sumber: Data Primer yang diolah, 2019

Berdasarkan tabel 12 dapat dilihat bahwa nilai signifikan 0,044 atau lebih kecil dari alpha 0,05 dapat disimpulkan bahwa terdapat pengaruh secara bersama-sama variabel Independensi, Komitmen Organisasi, Good Governance, dan Ketidakjelasan Peran terhadap Kinerja Auditor Pemerintah. 
Tabel 13

Hasil Uji Koefisien Determinasi (Adjusted $\boldsymbol{R}^{2}$ )

\begin{tabular}{cc}
\hline Model & Adjusted R Square \\
\hline 1 & .268 \\
\hline
\end{tabular}

Sumber: Data Primer yang diolah, 2019

Koefisien determinasi digunakan untuk mengukur dan melihat seberapa jauh kemampuan dari model regresi dalam menjelaskan variasi dependen (Nazaruddin dan Basuki, 2015). Tabel 13 menunjukan bahwa Adjusted $r$ square 0,268 yang artinya variabel Independensi, Komitmen Organisai, Good Governance, dan Ketidakjelasan Peran mampu menjelaskan variasi variabel Kinerja Auditor Pemerintah sebesar 26,8\% dan sisanya sebesar 73,2\% dijelaskan oleh variabel lain yang tidak diteliti.

\section{Pembahasan}

\section{Independensi}

Hasil penelitian ini diketahui variabel Independesi berpengaruh positif dan signifikan terhadap Kinerja Auditor Pemerintah, adanya pengaruh positif ditunjukkan dari nilai signifikan 0,044< <0,05. Hal ini menunjukkan bahwa Independensi menjadi salah satu pengaruh kinerja auditor pemerintah.

Penelitian yang dilakukan Trisnaningsih (2007) menyatakan bahwa independensi auditor akan berpengaruh positif pada kinerja auditor. Hal ini juga sama pada hasil penelitian Wibowo (2009) bahwa terdapat pengaruh positif independensi pada kinerja auditor. Independensi adalah salah satu penentu keberhasilan auditor pemerintah untuk melakukan tugasnya, apabila auditor tidak independen maka dapat dipastikan kinerja yang dihasilkan akan kurang maksimal dan melanggar kode etik atau aturan yang ada. Oleh sebab itu independensi sangat penting untuk kinerja auditor pemerintah.

\section{Komitmen Organisasi}

Hasil penelitian ini diketahui variabel Komitmen Organisasi berpengaruh positif dan signifikan terhadap Kinerja Auditor Pemerintah, adanya pengaruh positif ditunjukkan dari nilai signifikan $0,033<0,05$. Hal ini menunjukkan bahwa Komitmen Organisasi menjadi salah satu pengaruh kinerja auditor pemerintah. Penelitian yang dilakukan oleh Trisnaningsih (2007), Marganingsih dkk (2009), Sujana (2012), dan Wijaya dan Subagyo (2017) yang juga menyatakan bahwa pengaruh komitmen organisasi memiliki pengaruh positif terhadap kinerja auditor.

Komitmen organisasi menjadi salah satu penentu keberhasilan auditor pemerintah untuk melakukan tugasnya, apabila suatu komitmen organisasi yang tepat akan dapat memberikan sebuah motivasi yang tinggi yang nantinya akan berpengaruh positif pada kinerja auditor pemerintah.

\section{Good Governance}

Hasil penelitian ini diketahui variabel Good Governance berpengaruh positif dan signifikan terhadap Kinerja Auditor Pemerintah, Hal ini menunjukkan bahwa Good Governance menjadi salah satu pengaruh kinerja auditor pemerintah. Penelitian yang dilakukan oleh Hanna dan Friska (2013) bahwa pemahaman good governance memiliki pengaruh positif pada kinerja auditor. Widhi dan Erma (2015) menyatakan bahwa pemahaman good governance yang berpengaruh positif terhadap kinerja auditor pemerintah. Dengan demikian dapat disimpulkan bahwa good governance memiliki pengaruh positif terhadap kinerja auditor pemerintah. Semakin baik Good Governance yang dimiliki oleh suatu Instansi pemerintah, maka dapat mengatur dan membuat tata kerja audior agar bekerja sesuai dengan pekerjaan dan aturan yang berlaku. 


\section{Ketidakjelasan Peran}

Hasil penelitian ini diketahui variabel Ketidakjelasan Peran tidak berpengaruh terhadap Kinerja Auditor Pemerintah, Hal ini dikarenakan peran yang dimiliki atau tugas yang dimiliki auditor pemerintah yang berkerja di Kantor Inspektorat Daerah Istimewa Yogyakarta ini sudah sangat jelas, sehingga ketidakjelasan peran tidak berpengaruh.

\section{KESIMPULAN}

Tujuan dari penelitian ini adalah untuk menguji dan menganalisis pengaruh Independensi, Komitmen Organisasi, Good Governance, dan Ketidakjelasan Peran terhadap Kinerja Auditor Pemerintah. Penelitian ini telah menguji 4 hipotesis dengan kesimpulan 3 hipotesis diterima dan 1 tidak diterima. Kesimpulan dalam penelitian ini sebagai berikut: (1) Independensi berpengaruh positif terhadap Kinerja Auditor Pemerintah. Artinya Auditor Pemerintah semakin menerapkan sikap independensi, maka pengambilan keputusan audit tidak dipengaruhi oleh pihak manapun. (2) Komitmen Organisasi berpengaruh positif terhadap Kinerja Auditor Pemerintah. Artinya semakin baik komitmen organisasi yang dimiliki, maka akan memiliki motivasi yang tinggi yang nantinya akan berpengaruh positif pada kinerja auditor pemerintah. (3) Good Governance berpengaruh positif terhadap Kinerja Auditor Pemerintah. Artinya Semakin baik Good Governance yang dimiliki oleh suatu Instansi pemerintah, maka dapat mengatur dan membuat tata kerja audior agar bekerja sesuai dengan pekerjaan dan aturan yang berlaku. (4) Ketidakjelasan Peran tidak berpengaruh terhadap Kinerja Auditor Pemerintah. Artinya Auditor Pemerintah memilk peran dan tugas yang jelas.

\section{DAFTAR PUSTAKA}

Agustina, L. (2009). Pengaruh Konflik Peran, Ketidakjelasan Peran, dan Kelebihan Peran Terhadap Kepuasan Kerja dan Kinerja Auditor. Jurnal Akuntansi, 1(1), 40-69.

Alim, M. N. (2007). Pengaruh Kompetensi dan Independensi terhadap Kualitas Audit dengan Etika Auditor sebagai Variabel Moderasi. Makalah Simposium Nasional Akuntansi X Makassar, Makassar.

Christiawan, Y. J. (2002). Kompetensi dan Independensi Akuntan Publik: Refleksi Hasil Penelitian Empiris. Jurnal Akuntansi dan Keuangan, 4(2): 79-92.

Bamber, E. M., Doug Snowball, \& Richard M. T. (1989). Audit Structure and Its Relation To Role Conflict And Role Ambiguity. The Accounting Review, LXIV (2).

Elizabeth, H. \& Friska, F. (2013). Faktor-Faktor Yang Mempengaruhi Kinerja Auditor. Jurnal Bisnis dan Akuntansi, 15(1), 13 - 28.

Fanani, Z, Rheny A. H., \& Subroto, B. (2008). Pengaruh Struktur Audit, Konflik Peran dan Ketidakjelasan Peran Terhadap Kinerja Auditor. Jurnal Akuntansi dan Keuangan Indonesia, 5(2), 143 - 170.

Fransiskus, W., \& Subagyo. (2017). Pengaruh Konflik Peran, Komitmen Organisasi, dan Locus of Control Terhadap Kinerja Auditor. Jurnal Online Insan Akuntan, 2(1), 1 - 16.

Marganingsih, A., \& Martani, D. (2009). Analisis Variabel Anteseden Perilaku Auditor Internal Dan Konsekuensinya Terhadap Kinerja: Studi Empiris Pada Auditor di Lingkungann Aparat Pengawasan Intern Pemerintah - Lembaga Pemerintah Non Departemen. Makalah Simposium Nasional Akuntansi XII, Padang 2009.

Mulyadi. (2002). Auditing: Edisi Keenam. Buku 1. Jakarta: Salemba Empat.

Nazaruddin, I., \& Basuki, A. T. (2015). Analisis Stastistik Dengan Spss. Yogyakarta: Danisa Media. 
Ramadhan, S. (2011). Analisa Pengaruh Struktur Audit, Konflik Peran, Ketidakjelasan Peran, dan Pemahaman Good Governance Terhadap Kinerja Auditor pada KAP di Jakarta. Aktiva, 4(7), $1-26$.

Robbins, S. P. (2002). Perilaku Organisasi, Alih bahasa, Hadyana Pujaatmaka, Jakarta: PT Prenhallindo.

Sapariyah, R. A. (2011). Pengaruh Good Governance dan Independensi Auditor Terhadap Kinerja Auditor dan Komitmen Organisasi (Survey pada Kantor Akuntan Publik di Surakarta). Jurnal Ekonomi Bisnis dan Perbankan, 19(16).

Sujana, E. (2012). Pengaruh Kompetensi, Motivasi, Kesesuaian Peran dan Komitmen Organisasi Terhadap Kinerja Auditor Internal Inspektorat Pemerintah Kabupaten (Studi Pada Kantor Inspektorat Kabupaten Badung dan Buleleng). Jurnal Ilmiah Akuntansi dan Humanika Jinah, 2(1).

Sukriah, I., Akram, \& Inapty, B. A. (2009). Pengaruh Pengalaman Kerja, Independensi, Obyektifitas, Integritas dan Kompetensi Terhadap Kualitas Hasil Pemeriksaan. Makalah Simposium Nasional Aakuntansi XII Palembang.

Trisnaningsih, S. (2007). Independensi Auditor Dan Komitmen Organisasi Sebagai Mediasi Pengaruh Pemahaman Good Governance, Gaya Kepemimpinan, dan Budaya Organisasi Terhadap Kinerja Auditor. Makalah Simposium Nasional Akuntansi X Unhas Makassar: $1-56$.

Wati, E., Lismawati, \& Aprilia, N. (2010). Pengaruh Independensi, Gaya Kepemimpinan, Komitmen Organisasi, dan Pemahaman Good Governance Terhadap Kinerja Auditor Pemerintah (Studi pada Auditor Pemerintah di BPKP Perwakilan Bengkulu), Makalah Simposium Nasional Akuntansi XIII Purwokerto.

Wibowo. (2009). Pengaruh Independensi Auditor, Komitmen Organisasi, Gaya Kepemimpinan, Pemahaman Good Governance Terhadap Kinerja Auditor (Studi Empiris pada Kantor Akuntan Publik di daerah Istimewa Yogyakarta). Skripsi. Universitas Islam Indonesia.

Widyananda, Herman. (2008). Revitalisasi Peran Internal Auditor Pemerintah Untuk Penegakan Good Governance di Indonesia. Publikasi, Seminar, makalah, dan Sambutan. Universitas Padjadjaran.

Zurnali, C. (2010). Learning Organization, Competency, Organizational Commitment, dan Customer Orientation: Knowledge Worker - Kerangka Riset Manajemen Sumberdaya Manusia di Masa Depan. Bandung: UNPAD Press. 